\section{Michał Wojciechowski}

Uniwersytet Warmińsko-Mazurski, Olsztyn

m.wojciechowski@uwm.edu.pl

DOI: http://dx.doi.org/10.12775/BPTh.2017.006

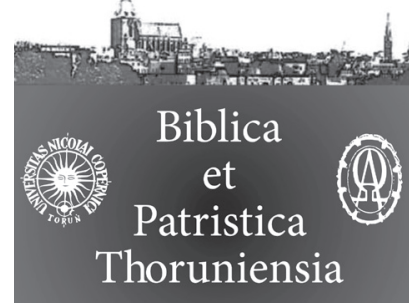

10 (2017) 1: 119-130

ISSN (print) 1689-5150

ISSN (online) 2450-7059

\title{
Pseudo-Cornutus, his religious physics and the New Testament
}

\section{Pseudo-Cornutus, jego religijna fizyka i Nowy Testament}

\begin{abstract}
Epidrome, a handbook of allegorical interpretation of Greek gods, is attributed, probably wrongly, to Cornutus, a Roman Stoic teacher from the first century AD. In this work, the gods are interpreted mostly as natural forces, densities, notions and phenomena, presented in accordance with the popular Stoic physics. Cosmological texts of the New Testament are far from this approach, although Stoic philosophy seems to have influenced the New Testament authors. This physical interpretation of gods could contribute to the minimal interest of the New Testament for the pagan religion. There are, however, some critical remarks on the status of the natural forces; it is reflected in Gal 4.8-9; Col 1.16; 2.15; Eph 1.21; 2.2; 6.12. In Epidrome there are also some minor common points with the New Testament, resulting from the similar milieu, as the use of terms archegos and monogenes, or destruction of the present world by fire.
\end{abstract}

Streszczenie. Epidrome, podręcznik alegorycznej interpretacji bogów greckich, przypisuje się, zapewne niesłusznie, Cornutusowi, stoickiemu nauczycielowi rzymskiemu z I wieku po Chr. W dziele tym bogowie są interpretowani głównie jako siły natury, stany skupienia, pojęcia i zjawiska, przedstawione zgodnie z popularną fizyką stoicką. Teksty kosmologiczne z Nowego Testamentu są odległe od tego podejścia, chociaż filozofia stoicka wpłynęła na jego autorów. Ta fizyczna interpretacja bogów mogła się przyczynić do znikomego zainteresowania Nowego Testamentu dla religii pogańskiej. Występują jednak krytyczne uwagi na temat takich sił, co znajduje odbicie w Ga 4,8-9; Kol 1,16; 2,15; Ef 1,21; 2,2; 6,12. W Epidrome można też znaleźć pomniejsze punkty wspólne z Nowym Testamentem, wynikłe z podobnego środowiska, np. użycie terminów archegos i monogenes, oraz zniszczenie obecnego świata w ogniu.

Keywords: Cornutus; Epidrome; ancient physics; ancient cosmology; stoicism; New Testament background.

Słowa kluczowe: Cornutus; Epidrome; fizyka starożytna; kosmologia starożytna; stoicyzm; tło Nowego Testamentu. 


\section{Introductory remarks: Cornutus and Epidrome}

$\mathrm{T}$ his article is a continuation of my book on Cornutus and his Epidrome which I have recently published in Polish. ${ }^{1}$ However, I shall raise here some new questions related to the physics and cosmology of this work in relation to the New Testament.

I stress physics, because the cosmology of Cornutus is less philosophical and more physical. Its main feature is interpreting Greek divinities as physical notions and phenomena. On the other hand, the influence of the Stoic cosmology on this work is not primary, although Epidrome is usually considered to be a fruit of Roman Stoicism. It is basically correct, but the Stoicism of Epidrome consists mainly in the wide-spread use of etymology and allegory in its interpretation of gods. $^{2}$

This work is called in Greek manuscripts: Epidrome ton kata ten Helleniken theologian paradedomenon; in Latin: Theologiae graecae compendium. In translation: "A review of traditions transmitted by Greek theology". The text has been critically edited ${ }^{3}$ and translated in many languages, although the English and French translations can be found only in unpublished dissertations. ${ }^{4}$ It has been studied mainly from the angle of Greek religion, but not very often.

Epidrome has come to us under the name of Cornutus. Lucius Annaeus Cornutus $^{5}$ was a prominent thinker and teacher from the Neronian Rome. Among his students were Persius and Lucan. He was highly praised for his works on literature and philosophy, but they were lost except of some quotations in later works. ${ }^{6}$ He wrote in Latin and Greek. His allegorical method supposedly influenced Christian authors. ${ }^{7}$

1 Pseudo-Cornutus, Przeglad. With a bibliography, which is published also in the web (academia.edu, ResearchGate). My studies of this subject were supported by a NCN grant (project 2013/09/B/HS1/00872).

2 On allegory and its function: Pépin, Mythe. Brisson, How Philosophers. Cf. Bremer, Interpretations; Cameron, Greek.

3 Cornuti..., ed. C. Lang; Anneo Cornuto, Compendio (with an Italian translation, I. Ramelli); Cornutus, Die griechischen; Lucius Annaeus Cornutus, Einführung (with German translations).

4 Hays, Lucius; Rocca-Serra L’Abrégé.

5 Cf. F. Bellandi, Anneo; S. Döpp, Satiriker; P.P.F. Gonzales, Cornutus; A.D. Nock, Kornutos; C. Torre, Cornuto.

6 R.S. Hays, Lucius; G. Rocca-Serra, L’Abrégé.

7 From Origen on. Cf. I. Ramelli, Cornutus in christlichem Umfeld, in: Cornutus, Griechische, 207-222. 
However, his authorship of Epidrome, his only extant work, raises serious doubts. This work was virtually unknown in the antiquity; only one ancient author noted that Cornutus had written something on the Greek gods. ${ }^{8}$ It became popular and quoted in the Middle Ages and later, when it was used as a textbook of Greek mythology and its symbolic meaning. Further, the work is written in a poor style, rather heavy and not always clear, even if the vocabulary is quite rich. It is not particularly original in content. It is often inconsistent. Cornutus we know about should know and write better.

Many scholars assume that Cornutus was its author after all, but it will be safer to deny his authorship. Nevertheless, he could have written something important about Greek theology. As it is indicated by the title, Epidrome, the work we have could be an abbreviated version of a longer treatise. This longer book could stem from Cornutus or his circle and be written in the first century $\mathrm{AD}$, whence the attribution. Epidrome could also have originated as notes taken by a student during the Cornutus' courses.

The literary form of the work allows to classify it as a textbook, comparable in structure to thematic encyclopedias. Therefore it does not follow the rhetoric rules. The work is of medium length and initially occupied one papyrus scroll. It is most often divided into 35 short chapters. ${ }^{9}$ Each one refers to one god or goddess or a group of them.

At the beginning, etymologies of their names are given. It leads to an interpretation of them as natural forces and phenomena. Divine names and attributes are interpreted accordingly. This interpretation is allegorical and most often has an etymology as a starting point. This method was known in Stoicism, but it had been invented earlier in relation to Homeric exegesis and continued by Anaxagoras, Metrodorus, Democritus and early Stoics. Most etymologies are also known from other sources, beginning from Cratylus. However, no other extant ancient work has collected this material so systematically. Perhaps Epidrome follows the lost work of Apollodorus of Athens, Peri theon. ${ }^{10}$

8 Theodoret, Graecarum affectionum curatio 62.3 .

9 The edition of Lang included this division, but some authors refer to its pages and verses. Further divisions into paragraphs and verses vary according to the edition, I quote the numbers of sections according to Cornutus, Griechische, e.g. 13.[1].

10 R. Münzel, De Apollodori. 


\section{Gods and physics}

Stoic physics and cosmology ${ }^{11}$ were related to philosophy and placed in its context. Stoics were interested in principles (archai), elements (stoicheia), boundaries (perata), place and void, active and passive principle, causation. They dealt with bodies, incorporeals and meanings (ta lekta). The universal reason (nous) rules the whole cosmos, perceived as living being. It was the key factor of Stoic monism. Further, the world is cyclical and runs towards periodic conflagration.

The cosmology of Epidrome seems sometimes to reflect these ideas, but is less philosophical and more physical. Gods are elements of nature, natural forces and notions from physics and chemistry.

If we read that Hera is air, Poseidon - water, Demeter with Hestia - earth, and Zeus - (or Apollo) fire and ether, at the first glance we identify them as the four elements of the world from the earlier philosophy. However, careful lecture shows that so-called elements are densities: gas, liquid, solid substance. Fire is plasma; Greeks have correctly guessed that the matter in the sun and stars must have special properties, being much hotter. (The textbooks of ancient philosophy are guilty of overlooking these conclusions.)

Some gods represent intermediary states: Hades the dense, humid air, Hephaestus is air with fire. There is also a discussion, whether flame is gas or plasma (cf. 19.[2]). Further, Ouranos/heaven is the universe around the earth. Apollo identified with Helios is the sun. Artemis is the moon.

Some terms refer to energy and movement. Cronus is time (chronos). Eros is understood as energy. Rhea and Oceanus independently represent flowing, the movement of the liquid (Oceanus in contrast with Thetis as a passive principle). Heracles is the force of nature. Pan is the cosmos as fertile and living.

Further allegorical interpretations refer to biological phenomena and to the human behaviour, in accordance with their typical understanding. EarthDemeter gives crops. Dionysus is depersonalized and identified with wine. Eros can be love and passion. Aphrodite - sexuality and fecundity. Asclepius - healing. Muses are cultural phenomena, Graces - social virtues. Ares and Enyo war and disruption.

Some other divine names try, according to Epidrome, to catch the reasonable order of the world. It touches the Stoic notion of Logos, but also the conception of the laws of nature as seen by physics. Zeus is so understood, although he remains the supreme, personal god. Hermes is also an allegory of mind in its various applications. Prometheus represents pronoia, both providence and

11 M.J. White, Stoic. Cf. S. Sambursky, Physics; Physical World. Cf. R.B. Todd, The Stoics. 
human foresight. Prometheia is related also to Hephaestus, practical mind, and Athena, the mind of Zeus (although Athena keeps the features of divine helper and saviour). Moira, Nemesis and Tyche express the idea of determinism.

Summing up, the ancient gods are here just names for earthly phenomena. According to it, the sages of old had taught about physics and other sciences disguised as mythical theology. Pseudo-Cornutus made an attempt to create a language for science, taking the mythological names as the starting point. It is not so strange, considering that in modern chemistry many elements have mythological names, as titanium, mercury, iridium, tantalum, plutonium. If the language of physics went further in this direction, we would call gas "hera" and plasma "zeus(ium)".

Therefore Epidrome is in its core irreligious. It tries to reduce religion to natural sciences. Gods are radically demythologized, even if the author did not realized the consequences of his approach.

\section{A background for the New Testament}

It seems remarkable that the New Testament does not contain any significant polemics with the pagan religion and philosophy. Abandoning idols is presupposed, but it rarely appears as a problem. Mentions of adultery can be interpreted as allusions to idolatry, but they are rather vague. Some other critical allusions can be listed (e.g. false prophet in the Revelation of John). Zeus and Hermes are mentioned occasionally in Acts 14.12-13, in the context of the naivety of pagan believers. The cult of Artemis in Ephesus is rather a social phenomenon than a religious one (Acts 19). Philosophy is scarcely mentioned (Col 2.8).

Various reasons can explain this attitude. One of them, I think, is the situation of pagan religion. It was strong on the social level and visible, but raised less and less religious feelings. They were associated with magic, mysteries, divine rulers etc. Morals were related to philosophy, not to the religious life.

It is remarkable, that in Gal 4.8-9, in a polemics against the pagan religion, gods are described as "elements" (stoicheia). ${ }^{12}$ "Formerly, when you did not know God, you were in bondage to beings that by nature are no gods; but now that you have come to know God, or rather to be known by God, how can you turn back again to the weak and beggarly elements, whose slaves you want to be once more?" (RSV, modified). It fits well with the understanding of Greek

12 A popular term, cf. Epidrome 3.[2]; 26.[1]; 35.[7]. 
divinities as densities or other elements of this world. They are by nature no gods, indeed.

Conceiving and interpreting gods as natural forces seem indeed to exclude a personal religion. Many centuries earlier gods were both natural forces and personal beings. Becoming mainly or only natural forces, depersonalized, they became no gods at all. If the vision of gods presupposed in Epidrome was widespread, there was no need to comment on them in the New Testament, because they constituted no challenge for the true religion.

Was this naturalistic interpretation popular? Our textbook presentation showed it as established. No conflict with the traditional religious feelings is presupposed. The cult is scarcely mentioned in Epidrome, only at its very end, and this single mention seems to be a lip-service to the official form of religion, with temples, prayers and sacrifices.

In the late antiquity we witness the importance of gods-saviours as Asclepius. They raised to importance perhaps already under the influence of early Christianity. The same can be true about monotheistic tendencies, resulting in the preeminence of Zeus as creator and father of humanity (as in the Olympic Oration of Dio Chrysostomus, Or. 12). Both tendencies are virtually absent in Epidrome, as they were most probably later.

\section{Christ and cosmic powers in Col 1.16; 2.15; Eph 1.21; 6.12}

In these texts something similar to Epidrome can be traced. Col 1.15-16 (RSV): 'He is the image of invisible God, the first-born of all creation; for him all things were created, in heaven and in earth, visible or invisible, whether thrones or dominions or principalities or authorities - all things were created through him and for him. Greek terms are thronoi eite kyriotetes eite archai eite exousiai. In this context they appear to be some important created beings.

In Col 2.15 two of these terms, tas archas kai tas exousias, are repeated, but in a different context: 'He disarmed the principalities and powers and made a public example of them, triumphing over them in him. Here these powers are clearly opposed to Christ and personified.

In Eph 1.21 we have once more four beings, confronted with Christ, who is 'far above all rule and authority and power and dominion, and above every name that is named'. In Greek: hyperano pases arches kai exousias kai dynameos kai kyriotetos. Here these beings, although important, remain lower if compared with Christ and belong to this world. "Named" refers to any thing that can be defined. 
In Eph 6.12 we read: 'For we are not contending against flesh and blood, but against the principalities (archas), against the powers (exousias), against the world rulers (kosmokratoras) of these present darkness, against spiritual hosts of wickedness in the heavenly places'.

The five Greek terms we have encountered are rather general and they were variously used, whence the difficulty of translating them. It is reflected in the inconsistencies of translations and in the differences between them. All the enumerations are obviously related what does not help much, because in three texts the forces in question are understood differently.

We have various explanations of these forces. ${ }^{13}$ They have been understood in Christian antiquity as angels, but if so, it is difficult to find why they are subdued and led in triumph in Col 2.15 and associated with wickedness in Eph 6.12? They could have been of demonic nature, but in this case there is another problem: why Col 1.16 makes them created by God and gives them honorable names? (And why pagan demons are considered real?). They could have been political authorities and social forces, but it does not fit well with their creation through Christ in Col 1.16. Finally, if they were impersonal cosmic forces, their opposition to Christ in Col 2.15 is hardly understandable, and moreover in Eph 6.12 they are personalized.

Perhaps the cosmic forces discussed in Epidrome could throw some light on the problem, being a lacking link in the chain. Why and how? The author has reduced Greek gods to the rank of natural, physical forces, elements and notions. It means first of all that they are real. For the believers of any religion that deifies the forces of nature their mere existence cannot be questioned - and quite rightly: sea, fire and so one do exist. On the other hand, their nature and properties have to be discussed and can be questioned.

If these gods are no gods at all, but natural forces, in the Jewish and Christian context they could and should to be understood as created elements of this world, as sun, moon, stars, and procreation in Genesis 1 . These forces are powerful and important, but created through Christ as in Col 1.16, and lower than him as in Eph 1.21.

Accordingly, they are no idols, false gods. However, they have some divine pretence they are inimical and therefore they need to be subdued by Christ. It means also that Christ is in control of physical phenomena. The language of the New Testament reflects the residual duality of divinities understood, as in Epidrome, basically as physical elements and forces, but with divine names.

13 Summarized in many commentaries, ad locum. Cf. G.H.C. MacGregor, Principalities. 
They are impersonal and natural, but still described in a personal and religious language.

It helps also to explain Eph 2.2: "you once walked, following the course of this world (kosmou), following the prince of the power of air (kata ton archonta tes exousias tou aerou), the spirit that is not at work in the sons of disobedience". The demonic forces are still related to physical elements, although they are personified (and the air is not Hera).

The terms describing cosmic forces in Colossians and Ephesians are only occasionally used in Epidrome in a comparable meaning. From terms in question, exousia, thronos, kyriotes and kosmokrator are absent. Next two, arche and dynamis, are frequent, but most often used in singular and in the general sense. However, the plural forms seem related to the New Testament use. In Epidrome 9.[3] there is a mention of archai as "beginnings, principles, factors" of gracious behaviour. Plural ton stoicheion dynameis in Epidrome 26.[1] denote indeed "forces of elements", or perhaps densities, falling down and coming up.

As Epidrome was a textbook, it should be taken as a specimen of widely held opinions; they were known in the first century AD and could influence the New Testament writers. It is certain that Paul and his circle had some knowledge of Stoicism and made appeal to it. It is manifest and widely acknowledged in moral questions, but the New Testament authors could know also the physical worldview of their contemporaries. It dispensed them from polemics against idolatry, because the idols were already replaced with natural forces. On the other hand, they did not want to accept physical world as an ultimate reality. Thence the expressions from Colossians and Ephesians, showing to the physical forces their place. This polemics resulted later in the confrontation between cosmic and Christian theologies in the patristic period. ${ }^{14}$

\section{Minor analogies}

If we compare vocabularies of Cornutus and the New Testament we can find some analogies. Some of them are unimportant and result from the accidental use of the similar expressions. Some others reflect the same background of the first century language and culture. ${ }^{15}$ Some of them, however, seem to refer to common religious ideas and are worth of quoting.

\section{Cf. J. Pépin, Théologie.}

15 P.W. Van den Horst, Cornutus. Some interesting items can be added to his list, but on the other hands many are of no importance. In my book on Cornutus, Wojciechowski, Pseudo-Cornutus, 33-36, I have listed about 30 items. 
- References to the tradition (Matt 15.3; 1 Cor 11.2; 15.3 and Epidrome 13.[1]). The terms as paradidomi, archaioi, palaioi, presbyteroi, used in such context, are common to Hellenism and to the Greek biblical books.

- Use of monogenes for the divine being (Jn 1.14.18; 3.16,18; 1 Jn 4.9 and Epidrome 27.[2] about Pan, the living and fertile world, in the monistic sense).

- Divine founder, archegos (Acts 3.15; 5.31; Hebr 2.10; 12.2 and Epidrome 6.[3] about Rhea).

- Divinity as the first and the last (Rev 1.8,17; 2.8; 21.6; 22.13 and Epidrome 28.[4] on Hestia); an element of the Greek religious language.

- This world will be destroyed in fire (2 P 3.10,12 and Epidrome 17.[5]; cf. 1.[2]). An element of the Stoic cosmology.

- Etymology of Apollo from destroying (apollynai: Rev 19.11 and Epidrome 32.[3]).

\section{Bibliography}

\section{Editions and translations of Epidrome}

Anneo Cornuto, Compendio di teologia greca, ed. I. Ramelli, Milano 2003.

Cornuti theologiae Graece Compendium, ed. C. Lang, Bibliotheca scriptorum Graecorum et Latinorum Teubneriana, Lipsiae 1881 (openlibrary.org).

Cornutus, Die griechischen Götter: ein Überblick über Namen, Bilder und Deutungen, ed. H.-G. Nesselrath, Scripta Antiquitatis Posterioris ad Ethicam REligionemque pertinentia 14, Tübingen 2009.

Hays R.S., Lucius Annaeus Cornutus' Epidrome (Introduction to the traditions of Greek theology). Introduction, translation, and notes, diss. Univ. of Texas at Austin, 1983.

Lucius Annaeus Cornutus, Einführung in die griechische Götterlehre, ed. P. Busch, J. Zangenberg, Texte zur Forschung, Darmstadt 2010.

Rocca-Serra G., L’Abrégé de Cornutus, diss. Paris IV 1988. / Cornutus. Abrégé de traditions relatives a la théologie grecque.

Wojciechowski M., Pseudo-Cornutus. Przeglą greckich poglądów na bogów (Epidrome), Olsztyn 2016.

\section{About Epidrome}

Alesso M., Los dioses griegos en el s. I: Hermes, Circe de Clasicos e Modernos 6(2001), pp. 13-29.

Baier T., Der Götterapparat in Silius Italicus, Aevum Antiquum N.S. 6(2006), pp. 275$-291$. 
Guastella G., Epea pteroenta: il volo delle parole in alcune interpretazioni degli antichi, Paideia 59(2004), pp. 221-234.

Boys-Stones G., Fallere Sollers. The Ethical Pedagogy of the Stoic Cornutus, w: Sorabji R., Sharples R.W., Greek Roman Philosophy 100 BC - 200 AD, London 2007, pp. 77-88.

Colafrancesco P., Iconografia e iconologia del dio Pan tra Servio e Virgilio, Invigilata Lucernis 23(2001), pp. 27-51.

Horst P.W. van der, Cornutus and the New Testament, Novum Testamentum 23(1981)2, pp. 165-172.

Kern O., Ein neues Zeugnis für Hermes Tychon, Archiv für Religionswissenschaft 30(1933), p. 205.

Krafft P, Die handschriftliche Überlieferung von C ornutus' Theologia Graeca, Heidelberg 1975.

Lucarini C.M., Atakta, Philologus 151(2007)1, pp. 164-172.

Most G.W., Cornutus and Stoic Allegoresis: A Preliminary Report, Aufstieg und Niedergang der römischen Welt II.36.3 (1989), pp. 2014-2065.

Münzel R., De Apollodori Peri theon libris, Bonn 1883.

Rives J.B., Phrygian Tales, Greek, Roman and Byzantine Studies 45(2005)3, pp. 223$-244$.

Rocca-Serra G., Exégèse allégorique et idéologie impériale; l'abrégé de Cornutus, w: Neronia 1977, Clermont-Ferrand 1982, pp. 61-72.

Rocca-Serra G., Anachorèse et paideia, in: Centro richerche e documentazione sull'antiquita classica, Atti (N.S. II) 12(1982-1983) = Neronia 3, pp. 11-19.

Rocca-Serra G., Notations médicales dans l'Abrégé de Cornutus, Revue Philosophique 154(1964), pp. 245-248.

Rocca-Serra G., Pour une édition de Cornutus, Bulletin de l’Association Guilaume Budé, 4. seria, 10(1963), pp. 348-350.

Schmidt B.H., De Cornuti Theologiae gr aecae compendio capita duo, Halis Saxonum 1912.

Tate J., Cornutus and the Poets, Classical Quarterly 23(1929), pp. 41-45.

Torres J.B., Roman Elements in Annaeus Cornutus's Epidromē, in: J.B. Brres Guerra (ed.), Vtroque sermone nostro. Bilingüismo social y literario en el imperio de Roma / Social and Literary Bilingualism in the Roman Empire, Pamplona 2011, pp. 41-54.

Torres J.B., "Deys" in Cornutus, Mnemosyne 62(2009)4, pp. 628-634.

\section{Lucius Annaeus Cornutus}

Bellandi F., Anneo Cornuto nelle «saturae» e nella "vita Persi», w: Gli Annei: una famiglia nella storia e nella cultura di Roma imperiale, ed. I. Gualandri, G. Mazzoli, Como 2003, pp. 185-210.

Ciaffi V., Intorno all'autore dell' Octavia, Rivista di filologia e di istruzione classica 1937, pp. 246-265. 
Cugusi P., Lucio Anneo Cornuto esegeta di Virgilio, in: Gli Annei: una famiglia nella storia e nella cultura di Roma imperiale, red. I. Gualandri, G. Mazzoli, Como 2003, pp. 211-244.

Döpp S., Ein Satiriker porträtiert seinen Lehrer: zu Persius sat. 5, 1-65, w: „Altera Ratio“: Klassische Philologie zwischen Subjektivität und Wissenschaft, Fs. W. Suerbaum, ed. M. Schauer [et al.], Stuttgart 2003, pp. 25-41.

Gianfranco A., Note a epigrafi tardoantiche (Miscellanea epigrafica. 2), Zeitschrift für Papyrologie und Epigraphik 2007, no. 160, pp. 41-49.

Gonzales P.P.F., Cornutus, in: Dictionnaire des philosophes antiques, Paris 1994, pp. 460-473.

Herrmann L., L. Annaeus Cornutus et sa rhétorique à Herennius Senecio, Latomus 39(1980), pp. 144-160.

Nock A.D., Kornutos, in: G. Wissowa, A. Pauly et al. (ed.), Real-Encyclopädie der classischen Altertumswissenschaft, Supplement 5, Stuttgart 1931, pp. 995-1005.

Ramelli I., Anneo Cornuto e gli Stoici romani, Gerión 21(2003)1, pp. 283-303.

Setaioli A., Interpretazioni stoiche ed epicuree in Servio e la tradizione dell'esegesi filosofica del mito e dei poeti a Roma (Cornuto, Seneca, Filodemo), International Journal of the Classical Tradition 10(2003-2004)3-4, pp. 335-376; 11(2004-2005)1, pp. 3-46.

Takács L., Hellenismus und Philhellenismus im Kreis von Cornutus, in: Neronia 7, Rome, l'Italie et la Grèce: hellénisme et philhellénisme au premier siècle ap. J.-C., red. Y. Perrin, Bruxelles 2007, pp. 312-322.

Takács L., The Story of a Fragment of L. Annaeus Cornutus, Acta Antiqua Academiae Scientiarum Hungaricae 44(2004)1, pp. 35-46.

Torre C., Cornuto, Seneca, i poeti e gli dei, w: Gli Annei: una famiglia nella storia e nella cultura di Roma imperiale, ed. I. Gualandri, G. Mazzoli, Como 2003, pp. $167-184$.

Zietsman J.C., Persius, Saturn and Jupiter, Akroterion 36(1991), pp. 94-103.

\section{Some general works}

Bremer J. (ed.), Interpretations of Greek Mythology, London 1988.

Brisson L., How Philosophers Saved Myths Myths. Allegorical Interpretation and Classical Mythology, Chicago 2004 (Introduction à la philosophie du mythe, vol. 1: Sauver les mythes, Paris 1996; Einführung in die Philosophie des Mythos, vol. 1: Antike, Mittelalter und Renaissance, Darmstadt 1996).

Cameron A., Greek Mythography in the Roman World, American Classical Studies 48, New York / Oxford 2004.

Dickey E., Ancient Greek Scholarship, Oxford 2007.

Engberg-Pedersen T., Cosmology and Self in Apostle Paul: The Material Spirit, Oxford 2010.

Hahn D.E., The Origins of Stoic Cosmology, Columbus 1977. 
MacGregor G.H.C., Principalities and Powers: The Cosmic Background of Paul's Thought, New Testament Studies 1()1, pp. 17-28.

Nuffelen P. van, Rethinking the Gods. Philosophical Readings of Religion in the PostHellenistic Period, Cambridge 2011.

Pépin J., Mythe et allégorie. Les origins grecques et les contestations judéo-chrétiennes, Paris ${ }^{2} 1976$.

Pépin J., Théologie cosmique et théologie chrétienne (Ambroise, Exam. I 1, 1-4), Paris 1964.

Pohlenz M., Die Stoa. Geschichte einer geistlichen Bewegung, 2 vol., Göttingen 1985$-1986$.

Sambursky S., Physics of the Stoics, London 1959.

Sambursky S., The Physical World of Late Antiquity, Princeton 1987.

Stoicorum Veterum Fragmenta [SVF], ed. I. ab Arnim [= H. Von Arnim], 3 vol., Stuttgart 1903-1905 (vol. 4, indices, M. Adler, Stuttgart 1924); with Italian translation: Stoici antichi. Tutti i frammenti, opr. R. Radice, Milano 2002.

Todd R.B., The Stoics and their Cosmology in the first and second centuries A. D., Aufstieg und Niedergang der römischen Welt II.36.3, Berlin-New York 1992, pp. 1365-1378.

White M.J., Stoic Natural Philosophy (Physics and Cosmology), in: B. Inwood (ed.), The Cambridge Companion to The Stoics, Cambridge 2003, pp. 124-152. 